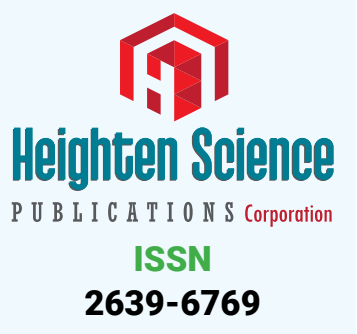

2639-6769

\title{
Growth Promoting Potential and Colonization Ability of Probiotics (Bacillus coagulans and Bacillus subtilis) on the Freshwater Prawn Macrobrachium rosenbergii Post-Larvae
}

\author{
Karthik M, Saravana Bhavan P* and Manjula T \\ Department of Zoology, Bharathiar University, Coimbatore-641046, Tamil Nadu, India
}

\begin{abstract}
*Address for Correspondence: Saravana Bhavan P, Department of Zoology, Bharathiar University, Coimbatore-641046, Tamil Nadu, India, Tel: +91-9842498138; Phone: +91-422-2428495; Fax: +91-422-2425706; Email: bhavan@buc.edu.in
\end{abstract}

Submitted: 20 December 2017

Approved: 12 January 2018

Published: 16 January 2018

Copyright: @2018 Karthik M, et al. This is an open access article distributed under the Creative Commons Attribution License, which permits unrestricted use, distribution, and reproduction in any medium, provided the original work is properly cited.

Keywords: $M$ rosenbergii; $B$ coagulans; $B$ subtilis; Growth; Protein

Check for updates

\section{Abstract}

The probiotic effects of Bacillus coagulans and Bacillus subtilis were studied on survival, growth, concentrations of basic biochemical constituents, activities of digestive enzymes, and their colony establishments in the gut of Macrobrachium rosenbergii post-larvae (PL). Eleven groups of PL $(2.03 \pm 0.05$ in length and $0.18 \pm 0.01 \mathrm{~g}$ in weight), each consists of 35 individuals maintained in $25 \mathrm{~L}$ of ground water and fed ad libitum with five serially diluted concentrations, $10^{-1}, 10^{-3}, 10^{-5}, 10^{-7}$ and $10^{-9}$ of $B$. coagulans, and $B$. subtilis incorporated diets containing $40 \%$ protein, for 45 days. Diet without incorporation of any of these probiotics was served as control. These probiotics were found to be alive in the respective feed even on day- 15 after their formulations. Significant improvement in survival, nutritional indices (weight gain, specific growth rate, food conversion ratio and protein efficiency ratio), contents of basic biochemical constituents (total protein, amino acid, carbohydrate and lipid) and activities of digestive enzymes (protease, amylase and lipase) were observed $(P<0.05)$, particularly in $10^{-7}$ concentration of $B$. coagulans, and $B$. subtilis incorporated diets fed $\mathrm{PL}$ when compared with control. The biochemical confirmation tests revealed that presence of Escherichia coli, Acetonobacter sp., Salmonella sp., and Pseudomonas sp., in the gut of control PL. In the gut of PL fed with B. coagulans incorporated diet, Acetonobacter sp., Salmonella sp., and Pseudomonas sp., were found to be competitively excluded, whereas, in the gut of PL fed with B. subtilis incorporated diet, Acetonobacter sp., and Salmonella sp., only were found to be excluded competitively. Actually, colonies of Bacillus sp., and Lactobacillus $\mathrm{sp}$., were found to be establishment in the gut of PL fed with $B$. coagulans, and B. subtilis incorporated diets. Overall, these probiotics incorporated diets produced better growth and survival due to better FCR and activities of digestive enzymes, which in turn led to better nutritional profile. Therefore they are recommended as feed additives for sustainable culture of $M$. rosenbergii.

\section{Introduction}

Aquaculture is one of the fastest growing food sectors in the world with main a Moto to supply rich protein food to the growing human population [1]. Beyond the fishes and other animals, the crustaceans, such as prawns, shrimps, crabs, lobsters and crayfish have a vital role in augmentation of protein production [2]. The freshwater prawn, Macrobrachium rosenbergii considered to be one of the crustacean species with increasing potential for aquaculture because of its commercial value and nutritious delicacy for human consumption cells added as dietary supplements to improve the health of aquatic animals. Generally, probiotics actively inhibit the colonization of potential pathogens in the digestive tract by antibiosis or by competition for nutrients and space, as well as alteration of the microbial metabolism and stimulating host immunity [3]. Studies on M. rosenbergii with some probiotics, Lactobacillus sporogenes, Bacillus subtilis, Saccharomyces cerevisiae, Lactobacillus acidophilus, Lactobacillus rhamnosus, Bifidobacterium longum, Bifidobacterium bifidum, Saccharomyces boulardii, Clostridium butyricum, Bacillus coagulans and Lactobacillus brevis, and their products, 
Biogen, Binifit ${ }^{\mathrm{TM}}$, LactoBacil ${ }_{\text {plus }}^{\circledR}$ and ViBact* [4-14], showed enhanced growth, survival, and nutritional profiles due to improved general health by establishing their colonies in the gut. Bacillus coagulans is a Gram-positive, lactic acid forming bacterial species. It is a good candidate for probiotic use, produces organic acids and possesses the capacity to sporulate. It secretes a bacteriocin, coagulin, which has activity against a broad spectrum of enteric microbes [15-17]. Bacillus subtilis is also a Gram-positive, lactic acid-forming bacterial species. A strain of $B$. subtilis 2335 has the ability to produce the antibiotic, Amicoumacin, which showed an in-vitro activity against Helicobacter pylori [18].

In the present study, B. coagulans and B. subtilis was individually incorporated at different concentrations with formulated diets and fed to M. rosenbergii PL for assessing their ability on promotion of growth and survival by enhancing the contents of basic biochemical constituents (total protein, amino acid, carbohydrate and lipid), and activities of digestive enzymes (protease, amylase and lipase). This was further to recommend the aquaculture industry with their optimum concentrations. Furthermore, to evaluate their competitive exclusion abilities of pathogenic bacteria, their colony establishments in the gut of PL were confirmed biochemically.

\section{Materials and Methods}

\section{Procurement of Macrobrachium rosenbergii PL and acclimation}

The post larvae (PL-20) of M. rosenbergii were procured from the Nursery pond at Singanallur, Coimbatore, Tamil Nadu, India. They were transported to the laboratory in polythene bags half filled with oxygenated pond water. They were then acclimated to the ambient laboratory condition in cement tanks $(6 \times 3 \times 3$ feet $)$ filled with groundwater for 2 weeks. The ground water satisfied the required physico-chemical parameters (Table 1).

During acclimation the prawns were fed with boiled egg albumin, live Artemia nauplii, and commercially available scampi feed. About $50 \%$ of tank water was routinely renewed every day to maintain a healthy environment. Aeration was also provided. These ensured sufficient oxygen supply to the prawns and an environment devoid of accumulated metabolic wastes. The unfed feeds, feces, molt and dead prawns were removed by siphoning.

\section{Procurement of probiotics and their sub-culture}

The lyophilized powder of Bacillus coagulans (MTCC 2302) and Bacillus subtilis (MTCC 121) were procured from Microbial Type Culture Collection (MTCC), Chandigarh, India. It was subjected to sub-culture with nutrient broth (Hi-media, India) containing the following ingredients as per manufacturer's protocol (Table 2) and incubated at 37 ${ }^{\circ} \mathrm{C}$ for 12 hours to observe their growth.

Agar $\left(12.0 \mathrm{~g} \mathrm{~L}^{-1}\right)$ was added with the nutrient broth, and the agar plates were incubated for $24 \mathrm{~h}$ at $37^{\circ} \mathrm{C}$ for checking the sterility. Then $20 \mu \mathrm{L}$ broth culture of B. coagulans, and B. subtilis were separately spread over the agar media (nutrient+agar) and kept for $24 \mathrm{~h}$ at $37^{\circ} \mathrm{C}$ to observe their growth (Figure 1).

\begin{tabular}{|c|c|c|}
\hline Parameter & Device/ Methodology & Value \\
\hline Temperature $\left({ }^{\circ} \mathrm{C}\right)$ & Mercury thermometer (Jenson \& Nicholson (India) Limited, Kolkata) & $22 \pm 0.2$ \\
\hline $\mathrm{pH}$ & ESICO, India, $\mu \mathrm{P}$ Based Water and Soil Analysis Kit, Model 1160 & $7.1 \pm 0.20$ \\
\hline $\operatorname{TDS}(\mathrm{g} / \mathrm{l})$ & APHA method (2005) [19] & $0.96 \pm 0.07$ \\
\hline $\mathrm{DO}_{2}(\mathrm{mg} / \mathrm{l})$ & Winkler's method (1888) [20] & $6.10 \pm 0.30$ \\
\hline Salinity $(\mathrm{mg} / \mathrm{l})$ & ESICO, India, $\mu \mathrm{P}$ Based Water and Soil Analysis Kit Model 1160 & $0.63 \pm 0.01$ \\
\hline $\mathrm{EC}(\mathrm{mS} / \mathrm{cm})$ & ESICO, India, $\mu \mathrm{P}$ Based Water and Soil Analysis Kit, Model 1160 & $1.01 \pm 0.01$ \\
\hline Ammonia (mg/l) & Phenol hypochloride method of Solorzano (1969) [21] & $0.030 \pm 0.007$ \\
\hline
\end{tabular}




\begin{tabular}{|c|c|}
\hline Table 2: Nutrient broth for $B$. coagulans and $B$. subtilis sub-culture. \\
\hline Ingredient compositions & Quantity $\left(\mathrm{g} \mathrm{L}^{-1}\right)$ \\
\hline Peptic digest of animal tissue & 5.0 \\
\hline Sodium chloride & 5.0 \\
\hline Beef extract & 1.5 \\
\hline Yeast extract & 1.5 \\
\hline Final pH (at $\left.25^{\circ} \mathrm{C}\right)$ & 7.4 \\
\hline
\end{tabular}

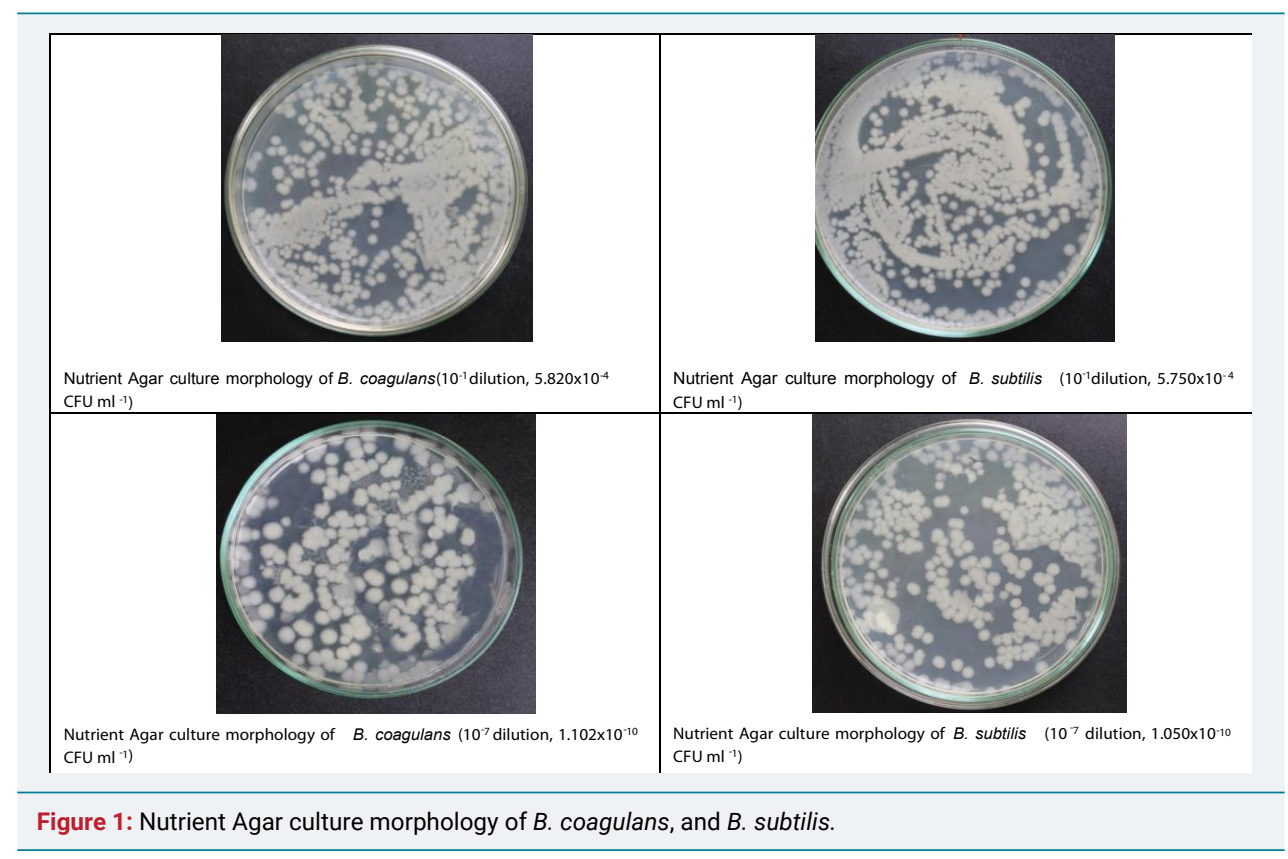

\section{Feed preparation}

The branded feed ingredients, included fishmeal, soybean meal, groundnut oilcake, wheat bran, tapioca flour, cod liver oil and egg were purchased from a local market. A Vitamin-B complex with vitamin-C purchased from a local pharmacy was also added. The experimental diets were prepared with selected feed ingredients as per "Pearson's square-method" using pre determined value of $45 \%$ protein content. Fishmeal, soybean meal and groundnut oilcake were used as protein sources; wheat bran and tapioca flour were used as carbohydrate sources; sunflower oil was used as lipid source; tapioca flour and egg albumin were served as binding agents; vitamin B complex with vitamin $\mathrm{C}$ was also added as essential micronutrients (Table 3).

The proportion of each ingredient required was calculated precisely for the premix along with tapioca powder, stream cooked and cooled at room temperature $\left(28^{\circ} \mathrm{C}\right)$. Egg albumin, sunflower oil, and vitamin B-complex with vitamin-C were then added one by one. B. coagulans, and B. subtilis were separately incorporated into the basal diet at $10^{-1}, 10^{-3}, 10^{-5}, 10^{-7}$ and $10^{-9}$ concentrations, each (diet-1 to diet-10). Diet ' 0 ' (without incorporation of any probiotic served as control. The dough was prepared for each formulation and pelletized separately to $2 \mathrm{~mm}$ pellets. These were dried in a thermostatic oven (M/s. Modern Industrial, Mumbai, India) at $40^{\circ} \mathrm{C}$ until they reached constant weight, and stored in airtight jars at room temperature $\left(28^{\circ} \mathrm{C}\right)$. The proximate composition of organic matters was determined according to AOAC [22]. The feeds were then placed in a hot air oven at slightly $>100^{\circ} \mathrm{C}$ and the loss of weight determined as the moisture content. The concentrations of minerals were estimated by using atomic absorption spectrophotometer (AAS) method (Table 4).

\section{Viability of probiotics in the respective diets}

The diet was freshly prepared once every 15 days to ensure high probiotic viability throughout the feeding trail. One gram of each diet prepared with $10^{-7}$ diluted probiotic 
concentration was taken and dissolved in autoclaved double distilled water $(10 \mathrm{~mL})$. A volume of $20 \mu \mathrm{L}$ was spread over MRS agar medium, incubated at $37^{\circ} \mathrm{C}$ for $24 \mathrm{~h}$ and the colony morphology observed was compared with the original B. coagulans, and $B$. subtilis sub-cultures morphology. The growth was recorded in all the culture plates except control. Therefore, the incorporated B. coagulans, and B. subtilis were alive in their respective diets even on day-15 after their formulation (Figure 2).

\begin{tabular}{|c|c|}
\hline Table 3: Ingredients used to formulate the basal diet. & \\
\hline & g/ $\mathbf{1 0 0 ~} \mathbf{~ g}$ \\
\hline Fasal ingredients $(\mathrm{BI})$ & 25 \\
\hline Froundnut oil cake & 25 \\
\hline Soybean meal & 25 \\
\hline Wheat bran & 10 \\
\hline Egg albumin & 7 \\
\hline Tapioca flour & 5 \\
\hline Sunflower oil & 2 \\
\hline Vitamin mix* & 1 \\
\hline Total & 100 \\
\hline
\end{tabular}

*BECOSULES CAPSULES, manufactured by Pfizer. Each capsule contains: Thiamine mononitrate (IP)-10 mg; Riboflavin (IP)-10 mg; Pyridoxine hydrochloride (IP )-3 mg; Vitamin B12 (as tablets 1:100) (IP)-15 mcg; Niacinamide (IP)-100 mg; Calcium pantothenate (IP)-50 mg; Folic acid (IP)-1.5 mg; Biotin (USP)-100 mcg; Ascorbic acid (IP)-150 mg.

\begin{tabular}{|c|c|}
\hline Table 4: Proximate components of basal diet prepared using various basal ingredients. \\
\hline Proximate components & Quantity (\%) \\
\hline Crude protein & 45.88 \\
\hline Total Nitrogen-free extract (carbohydrate) & 33.55 \\
\hline Ether extract (crude fat) & 7.28 \\
\hline Crude fiber & 1.57 \\
\hline Ash & 7.25 \\
\hline Moisture & 11.71 \\
\hline Gross energy & $4395 \mathrm{kcal} / \mathrm{kg}$ \\
\hline Calcium & 0.88 \\
\hline Phosphorus & 0.90 \\
\hline Iron & 0.82 \\
\hline Copper & $175.87 \mathrm{ppm}$ \\
\hline Salt & $25.86 \mathrm{ppm}$ \\
\hline
\end{tabular}

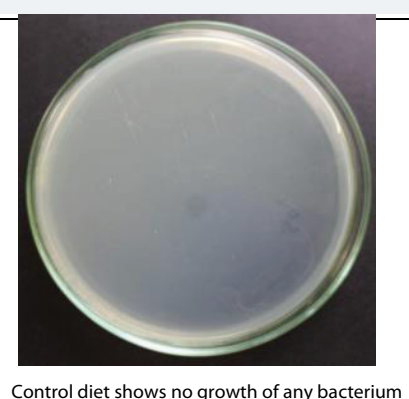

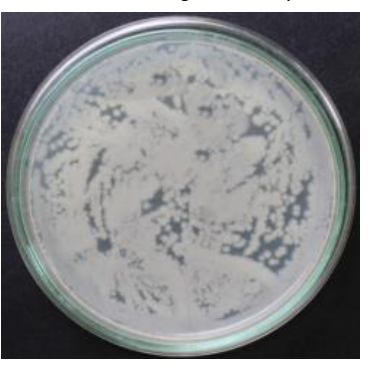

Experimental feed incorporated with B.coagulans $(10$ $1.102 \times 10^{-10} \mathrm{CFU} \mathrm{ml-1)}$ shows its presence and growth-7 dilution,

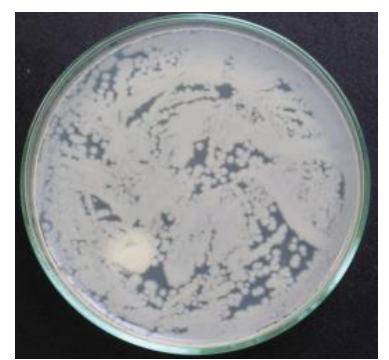

Experimental feed incorporated with B.subtilis $\left(10^{-7}\right.$ dilution, $1.050 \times 10$ ${ }^{10} \mathrm{CFU} \mathrm{ml}^{-1}$ ) shows its presence and growth

Figure 2: Viability of $B$. coagulans, and B. subtilis in experimental diets on day-15 after they were prepared. 


\section{Feeding trial}

M. rosenbergii PL-35 $(2.03 \pm 0.05$ in length and $0.18 \pm 0.01 \mathrm{~g}$ in weight $)$ were acclimated in plastic aquaria for three days during which they starved for $24 \mathrm{hr}$ before the commencement of the experiment. The feeding trail lasted 45 days. Four groups of 35 prawns were placed in $25 \mathrm{~L}$ aquaria in triplicate groups. The experimental groups were fed with the respective concentrations of $B$. coagulans, and B. subtilis incorporated feeds twice a day (8:00 AM and 8:00 PM) at 10\% of body weight. All the water was renewed daily and aerated constantly. The uneaten food particles, faeces, moults and dead prawns were removed by siphoning.

\section{Analysis of nutritional indices}

On the final day of feeding trial the morphometric data, such as the final length and weight were measured for calculating the growth parameters, such as survival rate (SR), Length gain (LG), weight gain (WG), specific growth rate (SGR), food conversion ratio (FCR), food conversion efficiency (FCE) and protein efficiency ratio (PER) [23].

SR (\%)=Total No. of PL alive at the end of experiment/ Total No. of PL introduced at the beginning of the experiment $\times 100$.

LG $(\mathrm{cm})=($ Final length $(\mathrm{cm})$-initial length $(\mathrm{cm})$. Weight gain, $W G(\mathrm{~g})=$ Final weight $(\mathrm{g})-$ initial weight (g).

SGR(\%) $=\log$ of final weight (g)- $\log$ of initial weight (g)/ No. of experimental days $\times 100$.

$$
\begin{aligned}
& \text { FCR }(\mathrm{g})=\text { Food consumed }(\mathrm{g}) / \mathrm{WG}(\mathrm{g}) \text {. } \\
& \text { PER(g)=WG (g)/protein intake }(\mathrm{g}) .
\end{aligned}
$$

\section{Estimation of concentrations of biochemical constituents}

On the final day, the concentrations of basic biochemical constituents were determined. Concentration of total protein was estimated by the method of [24]. The concentration of total amino acid was analyzed by according to Moore and Stein [25]. The concentration of total carbohydrate was estimated by the method of Roe [26]. The concentration of total lipid was determined according to [27] and estimated by the method of [28]. For these parameters, tissues from five prawns were pooled together from each group to constitute a single observation and three such observations were made to fulfill the triplicate analysis.

\section{Assays of digestive enzymes activities}

Activities of digestive enzymes were assayed before and after the feeding trial. The digestive tract of three prawns from each replicate were carefully dissected and homogenized in ice-cold distilled water and centrifuged at $9300 \mathrm{~g}$ under $4^{\circ} \mathrm{C}$ for 20 min. The supernatant was used as a crude enzyme source. Total protease activity was determined by casein-hydrolysis method of Furne et al. [29], where one unit of enzyme activity represented the amount of enzyme required to liberate $1 \mu \mathrm{g}$ of tyrosine per minute. Amylase activity was determined according to Bernfeld et al. [30], and the specific activity of amylase was calculated as milligrams of maltose liberated per gram of protein per hour $(\mathrm{mg} / \mathrm{g} / \mathrm{h})$. Lipase activity was determined by the method of Furne et al. [29]. One unit of lipase activity was defined as the amount of free fatty acid released from triacylglycerol per unit time estimated by the amount of $\mathrm{NaOH}$ required to maintain $\mathrm{pH}$ constant and represented as milli equivalents of alkali consumed.

\section{Analysis of gut microbial colonization}

The gut of control PLs, and the gut of experimental PLs fed with the best concentration of B. coagulans, and B. subtilis supplemented diet $\left(10^{-7}\right.$ dilution of each 
probiotic) were subjected to bacterial analysis. The PLs were deactivated by kept them in freezer at $-20^{\circ} \mathrm{C}$ for 10 minutes. The PL surface was sterilized with $50 \mathrm{ppm}$ formalin for 30 seconds to remove the external flora. The digestive tract was dissected and homogenized with phosphate buffered saline (pH-7.2) under aseptic condition. The homogenate was serially diluted up to $10^{-4}$ dilution. A volume of $0.5 \mathrm{~mL}$ of aliquot was mixed with agar nutrient broth and cultured for $24 \mathrm{~h}$ at $35^{\circ} \mathrm{C}$. Then, $0.1 \mathrm{~mL}$ broth culture was seeded over the surface of freshly prepared nutrient agar plates and incubated at $37{ }^{\circ} \mathrm{C}$ for $24 \mathrm{~h}$. The appearance of different bacterial colony was identified and confirmed through routine bacteriological tests [31]. The bacterial colonies were enumerated [Bacteria count $(\mathrm{CFU} / \mathrm{g})=$ Number of colonies $\times$ Dilution factor/ Volume of sample (g)].

\section{Statistical Analysis}

One way analysis of variance (ANOVA) using SPSS package (version 20.0) was used to determine the variations between control and treatment values, and between treatments, followed by Duncan multiple range test (DMRT) and the significances at $\mathrm{P}<0.05$ are mentioned. The data are represented as means \pm standard deviations.

\section{Results and Discussion}

\section{Growth and nutritional indices}

The survival, growth (LG and WG), specific growth rate, protein efficiency ratio were significantly increased in the prawns fed with B. coagulans, and B. subtilis supplemented diets when compared with control $(P<0.05)$. Among the different concentrations, $10^{-7}$ dilution of each probiotic incorporation was produced the best performance on these parameters. The lowest FCR recorded in this concentration of B. coagulans, and B. subtilis incorporations reflected the superior quality of the diets formulated (Tables 5 and 6).

Table 5: Nutritional indices of $M$. rosenbergii PL fed with $B$. coagulans incorporated feeds (initial length and weight of the PL: $2.86 \mathrm{~cm} ; 0.39 \mathrm{~g}$ ).

\begin{tabular}{|c|c|c|c|c|c|c|c|}
\hline \multirow{2}{*}{ Parameter } & \multirow{2}{*}{ Control } & \multicolumn{5}{|c|}{ Concentrations of $B$. coagulans } & \multirow{2}{*}{ F-value } \\
\hline & & $10^{-1}$ & $10^{-3}$ & $10^{-5}$ & $10^{-7}$ & $10^{-9}$ & \\
\hline SR (\%) & $87.61 \pm 1.64^{\mathrm{e}}$ & $89.52 \pm 1.64^{d}$ & $91.42 \pm 2.85^{\mathrm{bc}}$ & $93.33 \pm 1.64^{\mathrm{ab}}$ & $95.23 \pm 1.64^{\mathrm{a}}$ & $92.38 \pm 2.85^{\mathrm{abc}}$ & 6.12 \\
\hline Length(cm) & $3.73 \pm 0.05^{f}$ & $4.03 \pm 0.05^{e}$ & $4.26 \pm 0.10^{d}$ & $4.66 \pm 0.11^{b}$ & $4.98 \pm 0.01^{\mathrm{a}}$ & $4.44 \pm 0.05^{c}$ & 146.68 \\
\hline $\mathrm{LG}(\mathrm{g})$ & $0.86 \pm 0.05^{f}$ & $1.16 \pm 0.04^{e}$ & $1.40 \pm 0.05^{d}$ & $1.80 \pm 0.10^{\mathrm{b}}$ & $2.11 \pm 0.07^{\mathrm{a}}$ & $1.57 \pm 0.04^{c}$ & 105.14 \\
\hline Weight(cm) & $0.78 \pm 0.03^{f}$ & $0.93 \pm 0.01^{e}$ & $1.14 \pm 0.01^{\mathrm{d}}$ & $1.45 \pm 0.04^{b}$ & $1.61 \pm 0.01^{\mathrm{a}}$ & $1.33 \pm 0.01^{c}$ & 476.46 \\
\hline WG (g) & $0.39 \pm 0.04^{f}$ & $0.54 \pm 0.02^{\mathrm{e}}$ & $0.75 \pm 0.02^{d}$ & $1.06 \pm 0.04^{b}$ & $1.22 \pm 0.02^{\mathrm{a}}$ & $0.94 \pm 0.02^{c}$ & 340.76 \\
\hline SGR (\%) & $0.76 \pm 0.03^{e}$ & $0.87 \pm 0.02^{d}$ & $0.96 \pm 0.02^{c}$ & $1.07 \pm 0.02^{\mathrm{ab}}$ & $1.11 \pm 0.02^{\mathrm{a}}$ & $1.03 \pm 0.02^{\mathrm{b}}$ & 63.61 \\
\hline FCR (g) & $3.53 \pm 0.14^{\mathrm{a}}$ & $3.24 \pm 0.12^{b}$ & $2.49 \pm 0.06^{c}$ & $2.12 \pm 0.08^{d}$ & $1.69 \pm 0.02^{\mathrm{e}}$ & $2.00 \pm 0.04^{d}$ & 169.41 \\
\hline PER (g) & $0.33 \pm 0.03^{e}$ & $0.76 \pm 0.07^{d}$ & $0.94 \pm 0.02^{c}$ & $1.10 \pm 0.04^{b}$ & $1.38 \pm 0.23^{\mathrm{a}}$ & $1.17 \pm 0.02^{b}$ & 229.80 \\
\hline
\end{tabular}

Each value is mean \pm standard deviation of three individual observations.

Mean values within the same row sharing different alphabetical letter superscripts are statistically significant at $\mathrm{P}<0.05$ (one-way ANOVA and subsequent post hoc multiple comparison with DMRT).

SR, Survival Rate; LG, Length Gain; WG, Weight Gain, SGR, Specific Growth Rate; FCR, Food Conversion Ratio; PER, Protein Efficiency Ratio.

Table 6: Nutritional indices of M. rosenbergii PL fed with B. subtilis incorporated feeds (initial length and weight of the PL: $2.86 \mathrm{~cm} ; 0.39 \mathrm{~g}$ ).

\begin{tabular}{|c|c|c|c|c|c|c|c|}
\hline \multirow{2}{*}{ Parameter } & \multirow{2}{*}{ Control } & \multicolumn{5}{|c|}{ Concentrations of $B$. subtilis } & \multirow{2}{*}{ F-value } \\
\hline & & $10^{-1}$ & $10^{-3}$ & $10^{-5}$ & $10^{-7}$ & $10^{-9}$ & \\
\hline SR (\%) & $87.61 \pm 1.64^{c}$ & $90.46 \pm 1.64^{\mathrm{bc}}$ & $91.42 \pm 2.85^{\mathrm{bc}}$ & $94.28 \pm 2.85^{\mathrm{ab}}$ & $96.19 \pm 1.64^{\mathrm{a}}$ & $93.33 \pm 1.64^{\mathrm{ab}}$ & 6.10 \\
\hline Length(cm) & $3.33 \pm 0.05^{f}$ & $3.53 \pm 0.05^{e}$ & $3.96 \pm 0.05^{d}$ & $4.40 \pm 0.10^{b}$ & $4.73 \pm 0.05^{a}$ & $4.26 \pm 0.05^{c}$ & 192.12 \\
\hline LG(g) & $0.46 \pm 0.05^{e}$ & $0.66 \pm 0.05^{d}$ & $1.23 \pm 0.15^{c}$ & $1.53 \pm 0.05^{b}$ & $1.86 \pm 0.05^{a}$ & $1.40 \pm 0.10$ & 109.44 \\
\hline Weight(cm) & $0.78 \pm 0.03^{f}$ & $1.03 \pm 0.01^{e}$ & $1.20 \pm 0.02^{\mathrm{d}}$ & $1.46 \pm 0.01^{b}$ & $1.78 \pm 0.01^{\mathrm{a}}$ & $1.38 \pm 0.02^{c}$ & 713.39 \\
\hline WG (g) & $0.39 \pm 0.04^{f}$ & $0.63 \pm 0.02^{\mathrm{e}}$ & $0.82 \pm 0.01^{d}$ & $1.05 \pm 0.03^{b}$ & $1.39 \pm 0.02^{\mathrm{a}}$ & $0.99 \pm 0.03^{c}$ & 525.05 \\
\hline SGR (\%) & $0.80 \pm 0.03^{e}$ & $0.91 \pm 0.03^{d}$ & $0.99 \pm 0.01^{c}$ & $1.11 \pm 0.02^{\mathrm{a}}$ & $1.16 \pm 0.02^{\mathrm{a}}$ & $1.04 \pm 0.02^{b}$ & 69.36 \\
\hline FCR $(g)$ & $4.11 \pm 0.43^{a}$ & $2.66 \pm 0.10^{b}$ & $2.17 \pm 0.03^{c}$ & $1.65 \pm 0.01^{\text {de }}$ & $1.46 \pm 0.02^{\mathrm{e}}$ & $1.85 \pm 0.05^{c}$ & 83.98 \\
\hline $\operatorname{PER}(\mathrm{g})$ & $0.15 \pm 0.01^{f}$ & $0.88 \pm 0.03^{e}$ & $1.08 \pm 0.01^{d}$ & $1.41 \pm 0.01^{b}$ & $1.69 \pm 0.02^{a}$ & $0.97 \pm 0.03^{c}$ & 1.81 \\
\hline
\end{tabular}

Each value is mean \pm standard deviation of three individual observations.

Mean values within the same row sharing different alphabetical letter superscripts are statistically significant at $P<0.05$ (one-way ANOVA and subsequent post hoc multiple comparison with DMRT).

SR, Survival Rate; LG, Length Gain; WG, Weight Gain, SGR, Specific Growth Rate; FCR, Food Conversion Ratio; PER, Protein Efficiency Ratio. 


\section{Concentrations of basic biochemical constituents and activities of digestive enzymes}

The concentrations of total protein, amino acid, carbohydrate and lipid were significantly increased $(P<0.05)$ in test prawns fed with $B$. coagulans, and B. subtilis supplemented diets when compared with control (Tables 7 and 8 ). These were because of the significant increases $(P<0.05)$ in activities of protease, amylase and lipase (Tables 7 and 8), which ultimately produced better digestion and absorption of nutrients. Among the different concentrations, $10^{-7}$ dilution of each probiotic incorporation was produced the best performance on these parameters, which in turn responsible for better survival and growth of $M$. rosenbergii.

\section{Gut microbial population}

The biochemical confirmation tests revealed that presence of Escherichia coli, Acetonobacter sp., Salmonella sp., and Pseudomonas sp., in the gut of control PL. In the gut of PL fed with B. coagulans incorporated diet, Acetonobacter sp., Salmonella sp., and Pseudomonas sp., were found to be competitively excluded, whereas, in the gut of PL fed with B. subtilis incorporated diet, Acetonobacter sp., and Salmonella sp., only were found to be excluded competitively. Actually, colonies of Bacillus sp., and Lactobacillus sp., were found to be establishment in the gut of PL fed with B. coagulans, and B. subtilis incorporated diets (Tables 9,10; Figsures 3-5).

Table 7: Concentrations of basic biochemical constituents and activities of digestive enzymes in M. rosenbergii PL fed with B. coagulans incorporated feeds.

\begin{tabular}{|c|c|c|c|c|c|c|c|c|}
\hline \multirow{2}{*}{\multicolumn{2}{|c|}{ Parameters }} & \multirow{2}{*}{ Control } & \multicolumn{5}{|c|}{ Concentrations of $B$. coagulans } & \multirow{2}{*}{ F-value } \\
\hline & & & $10^{-1}$ & $10^{-3}$ & $10^{-5}$ & $10^{-7}$ & $10^{-9}$ & \\
\hline \multirow{4}{*}{$\begin{array}{c}\text { Biochemical } \\
\text { (mg/g wet. tissue) }\end{array}$} & Protein & $42.70 \pm 1.70^{\mathrm{e}}$ & $50.53 \pm 2.27^{d}$ & $58.18 \pm 2.00^{c}$ & $71.2 \pm 1.22^{b}$ & $80.83 \pm 2.36^{a}$ & $62.95 \pm 1.95^{c}$ & 121.90 \\
\hline & Amino acid & $20.97 \pm 1.20^{f}$ & $29.17 \pm 0.80^{e}$ & $37.05 \pm 1.50^{\mathrm{d}}$ & $48.63 \pm 1.78^{b}$ & $54.39 \pm 1.15^{\mathrm{a}}$ & $42.37 \pm 1.56^{c}$ & 131.96 \\
\hline & Carbohydrate & $12.58 \pm 0.30^{f}$ & $14.19 \pm 0.50^{\mathrm{e}}$ & $18.19 \pm 0.82^{d}$ & $24.82 \pm 0.78^{b}$ & $27.97 \pm 0.91^{\mathrm{a}}$ & $21.24 \pm 0.52^{c}$ & 235.47 \\
\hline & Lipid & $6.96 \pm 0.21^{f}$ & $10.24 \pm 0.58^{e}$ & $14.84 \pm 0.15^{d}$ & $18.38 \pm 0.39^{b}$ & $23.96 \pm 0.41^{\mathrm{a}}$ & $17.6 \pm 0.31^{c}$ & 688.12 \\
\hline \multirow{3}{*}{$\begin{array}{c}\text { Digestive Enzymes (U/ } \\
\text { mg protein) }\end{array}$} & Protease & $1.86 \pm 0.13^{e}$ & $2.33 \pm 0.12^{\mathrm{d}}$ & $2.74 \pm 0.11^{c}$ & $2.99 \pm 0.11^{c}$ & $3.27 \pm 0.10^{\mathrm{a}}$ & $2.80 \pm 0.01^{\mathrm{bc}}$ & 56.68 \\
\hline & Amylase & $0.73 \pm 0.09^{e}$ & $1.09 \pm 0.09^{d}$ & $1.38 \pm 0.14^{\mathrm{d}}$ & $2.07 \pm 0.08^{b}$ & $2.31 \pm 0.08^{\mathrm{a}}$ & $1.81 \pm 0.08^{c}$ & 110.65 \\
\hline & Lipase* & $0.20 \pm 0.01^{f}$ & $0.43 \pm 0.01^{\mathrm{e}}$ & $0.50 \pm 0.01^{d}$ & $0.57 \pm 0.01^{b}$ & $0.62 \pm 0.07^{a}$ & $0.54 \pm 0.01^{c}$ & 489.45 \\
\hline
\end{tabular}

Each value is mean \pm standard deviation of three individual observations. ${ }^{*}$, unit $\times 10^{3}$

Mean values within the same row sharing different alphabetical letter superscripts are statistically significant at $\mathrm{P}<0.05$ (one-way ANOVA and subsequent post hoc multiple comparison with DMRT).

Table 8: Concentrations of basic biochemical constituents and activities of digestive enzymes in $M$. rosenbergii PL fed with $B$. subtilis incorporated feeds.

\begin{tabular}{|c|c|c|c|c|c|c|c|c|}
\hline \multirow{2}{*}{\multicolumn{2}{|c|}{ Parameters }} & \multirow{2}{*}{ Control } & \multicolumn{5}{|c|}{ Concentrations of $B$. subtilis } & \multirow{2}{*}{ F-value } \\
\hline & & & $10^{-1}$ & $10^{-3}$ & $10^{-5}$ & $10^{-7}$ & $10^{-9}$ & \\
\hline \multirow{4}{*}{$\begin{array}{c}\text { Biochemical } \\
\text { (mg/g wet. tissue) }\end{array}$} & Protein & $46.68 \pm 3.21^{f}$ & $55.67 \pm 2.45^{\mathrm{e}}$ & $62.10 \pm 3.34^{\mathrm{d}}$ & $76.01 \pm 1.85^{b}$ & $86.18 \pm 2.45^{\mathrm{a}}$ & $68.51 \pm 2.45^{c}$ & 84.86 \\
\hline & Amino acid & $22.62 \pm 2.82^{f}$ & $39.60 \pm 2.00^{\mathrm{e}}$ & $41.47 \pm 2.15^{d}$ & $51.37 \pm 2.15^{b}$ & $60.80 \pm 1.41^{\mathrm{a}}$ & $46.66 \pm 1.41^{c}$ & 132.25 \\
\hline & Carbohydrate & $12.65 \pm 0.74^{\mathrm{a}}$ & $15.13 \pm 1.55^{\mathrm{a}}$ & $20.54 \pm 1.77^{a}$ & $24.81 \pm 1.01^{\mathrm{a}}$ & $29.60 \pm 1.31^{\mathrm{a}}$ & $22.03 \pm 0.46^{\mathrm{a}}$ & 1.00 \\
\hline & Lipid & $8.32 \pm 0.47^{f}$ & $11.09 \pm 0.57^{\mathrm{e}}$ & $16.87 \pm 1.54^{\mathrm{d}}$ & $20.17 \pm 0.34^{b}$ & $24.28 \pm 0.60^{\mathrm{a}}$ & $20.90 \pm 0.74^{c}$ & 925.15 \\
\hline \multirow{3}{*}{ Digestive Enzymes (U/ mg protein) } & Protease & $1.60 \pm 0.13^{d}$ & $1.80 \pm 0.18^{c}$ & $2.01 \pm 0.06^{b}$ & $2.17 \pm 0.06^{b}$ & $2.64 \pm 0.10^{\mathrm{a}}$ & $2.03 \pm 0.05^{b}$ & 29.96 \\
\hline & Amylase & $0.42 \pm 0.05^{\mathrm{e}}$ & $0.73 \pm 0.09^{e}$ & $1.13 \pm 0.09^{d}$ & $1.49 \pm 0.47^{\mathrm{bc}}$ & $2.14 \pm 0.08^{\mathrm{a}}$ & $1.64 \pm 0.04^{b}$ & 25.67 \\
\hline & Lipase* & $0.18 \pm 0.01^{\mathrm{e}}$ & $0.39 \pm 0.01^{d}$ & $0.41 \pm 0.02^{\text {cd }}$ & $0.48 \pm 0.02^{b}$ & $0.55 \pm 0.02^{\mathrm{a}}$ & $0.43 \pm 0.01^{b c}$ & 138.04 \\
\hline
\end{tabular}

Each value is mean \pm standard deviation of three individual observations. ${ }^{*}$, unit $\times 10^{3}$

Mean values within the same row sharing different alphabetical letter superscripts are statistically significant at $\mathrm{P}<0.05$ (one-way ANOVA and subsequent post hoc multiple comparison with DMRT).

Table 9: Colony formation units (CFU) of $B$. coagulans and $B$. subtilis in the gut of $M$. rosenbergii PL fed with respective probiotics incorporated diets at their best concentrations.

\begin{tabular}{|c|c|c|}
\hline Isolated species & Control & B. coagulans \\
\hline E. coli & $\mathrm{P}\left(4.096 \times 10^{-7}\right)$ & $\mathrm{P}\left(2.123 \times 10^{-7}\right)$ \\
\hline Acetonobacter sp. & $\mathrm{P}\left(3.250 \times 10^{-7}\right)$ & $\mathrm{A}$ \\
\hline Salmonella sp. & $\mathrm{P}\left(3.252 \times 10^{-7}\right)$ & $\mathrm{P}\left(3.425 \times 10^{-7}\right)$ \\
\hline Pseudomonas sp. & $\mathrm{P}\left(4.420 \times 10^{-7}\right)$ & $\mathrm{A}$ \\
\hline Bacillus sp. & $\mathrm{A}$ & $\mathrm{A}$ \\
\hline Lactobacillus sp. & $\mathrm{A}$ & $\mathrm{P}\left(3.645 \times 10^{-7}\right)$ \\
\hline P, Present; A, Absent; CFU, Colony Formation Unit (originally counted at $\left.10^{-4}\right)$. & $\mathrm{P}\left(3.515 \times 10^{-7}\right)$ \\
\hline
\end{tabular}


Table 10: Confirmative results of biochemical tests for microflora in the gut of $M$. rosenbergii $P L$ fed with $B$. coagulans, and $B$. subtilis incorporated diets.

\begin{tabular}{|c|c|c|c|c|c|c|c|c|c|c|c|}
\hline \multirow{2}{*}{ Test } & \multicolumn{4}{|c|}{ Control } & \multicolumn{3}{|c|}{ B. coagulans } & \multicolumn{4}{|c|}{ B. subtilis } \\
\hline & E.c & Ac. & Sa. & Ps. & E.c & Ba. & La. & E.c & Ps. & Ba. & La. \\
\hline Gram's staining & - & - & - & - & - & + & + & - & - & + & + \\
\hline Motility test & + & + & + & + & + & + & + & + & + & + & + \\
\hline Indole test & + & - & - & - & + & - & - & + & - & - & - \\
\hline Methyl red test & + & - & - & - & + & - & - & + & - & - & - \\
\hline Voges-Proskauer test & - & + & + & - & - & + & - & - & - & + & - \\
\hline Citrate utilization test & - & + & + & + & - & + & - & - & + & + & - \\
\hline Starch hydrolases & + & - & + & - & + & + & + & + & - & + & + \\
\hline Gelatin hydrolases & + & - & + & + & + & + & + & + & + & + & + \\
\hline Nitrate reduction test & + & - & + & + & + & - & + & + & + & - & + \\
\hline Oxidase test & + & + & - & + & + & - & - & + & + & - & - \\
\hline Catalase test & - & - & - & + & - & + & + & - & + & + & + \\
\hline Glucose test & A & A & A & A & A & A & A & A & A & A & A \\
\hline mLactose test & A & A & A & NA & A & A & A & A & NA & A & A \\
\hline Sucrose test & A & A & A & A & A & A & A & A & A & A & A \\
\hline Manitol test & A & A & A & A & A & NA & A & A & A & NA & A \\
\hline Maltose test & $\mathrm{Na}$ & NA & NA & A & $\mathrm{Na}$ & NA & NA & $\mathrm{Na}$ & A & NA & NA \\
\hline
\end{tabular}

+, Positive; -, Negative; A, Acid production; NA, No acid production; E.c, E. coli; Ac, Acinetobacter sp.; Sa, Salmonella sp.; Ps, Pseudomonas sp.; Ba, Bacillus sp.; Ls, Lactobacillus sp.

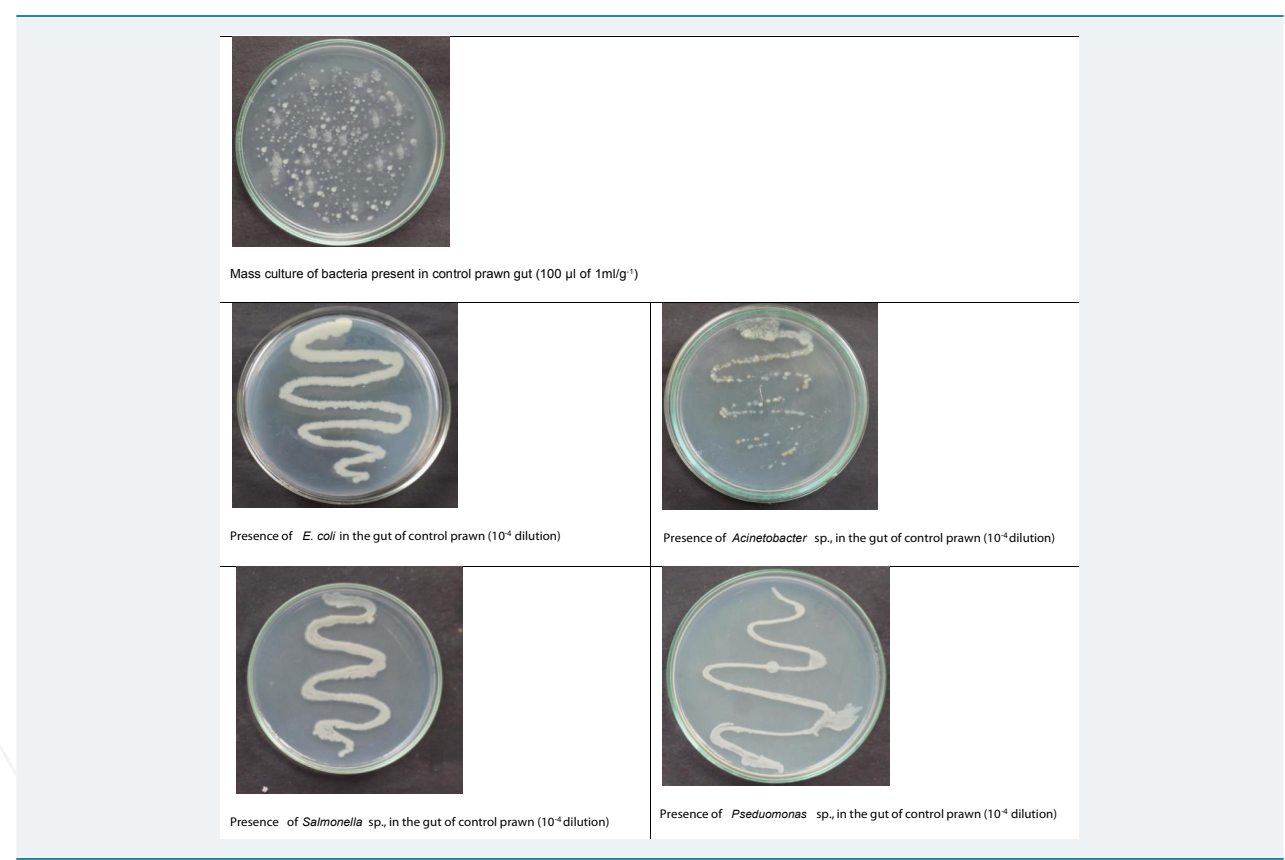

Figure 3: Nutrient agar streak plate morphology of bacteria present in control prawn gut.

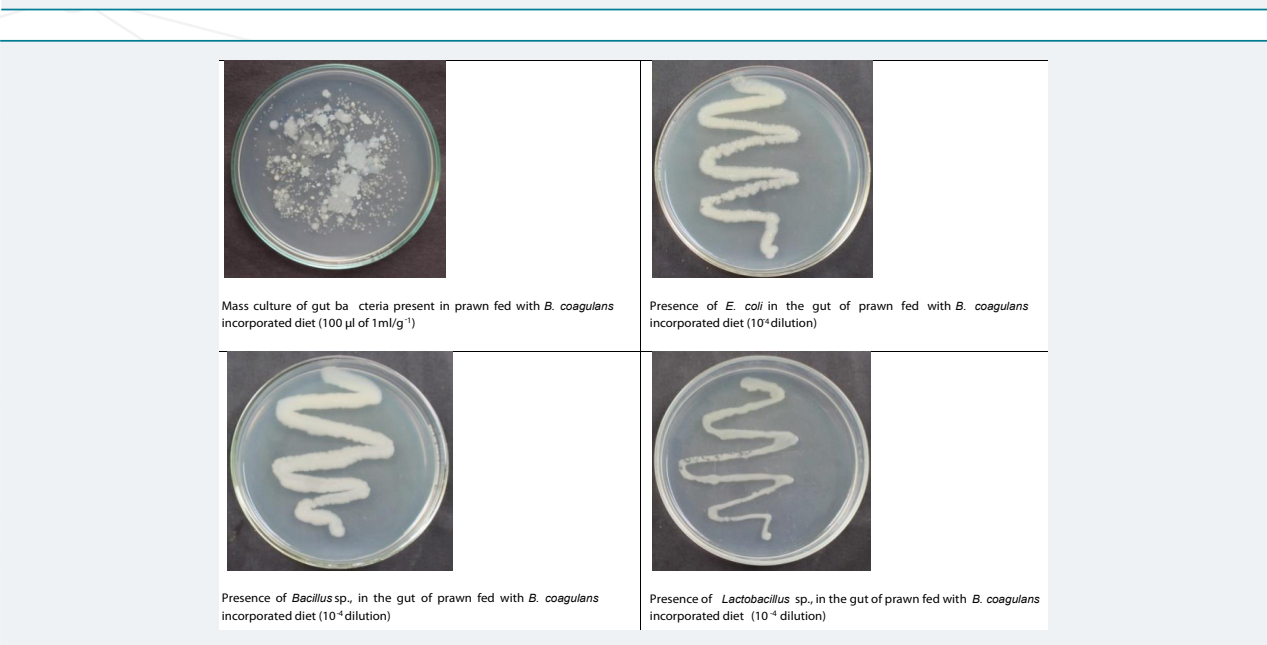

Figure 4: Nutrient agar streak plate morphology of bacteria present in the gut of prawns fed with $B$. coagulans (10-7 dilution, $1.102 \times 10^{-10} \mathrm{CFU} \mathrm{\textrm {ml } ^ { - 1 }}$ ) incorporated diet. 


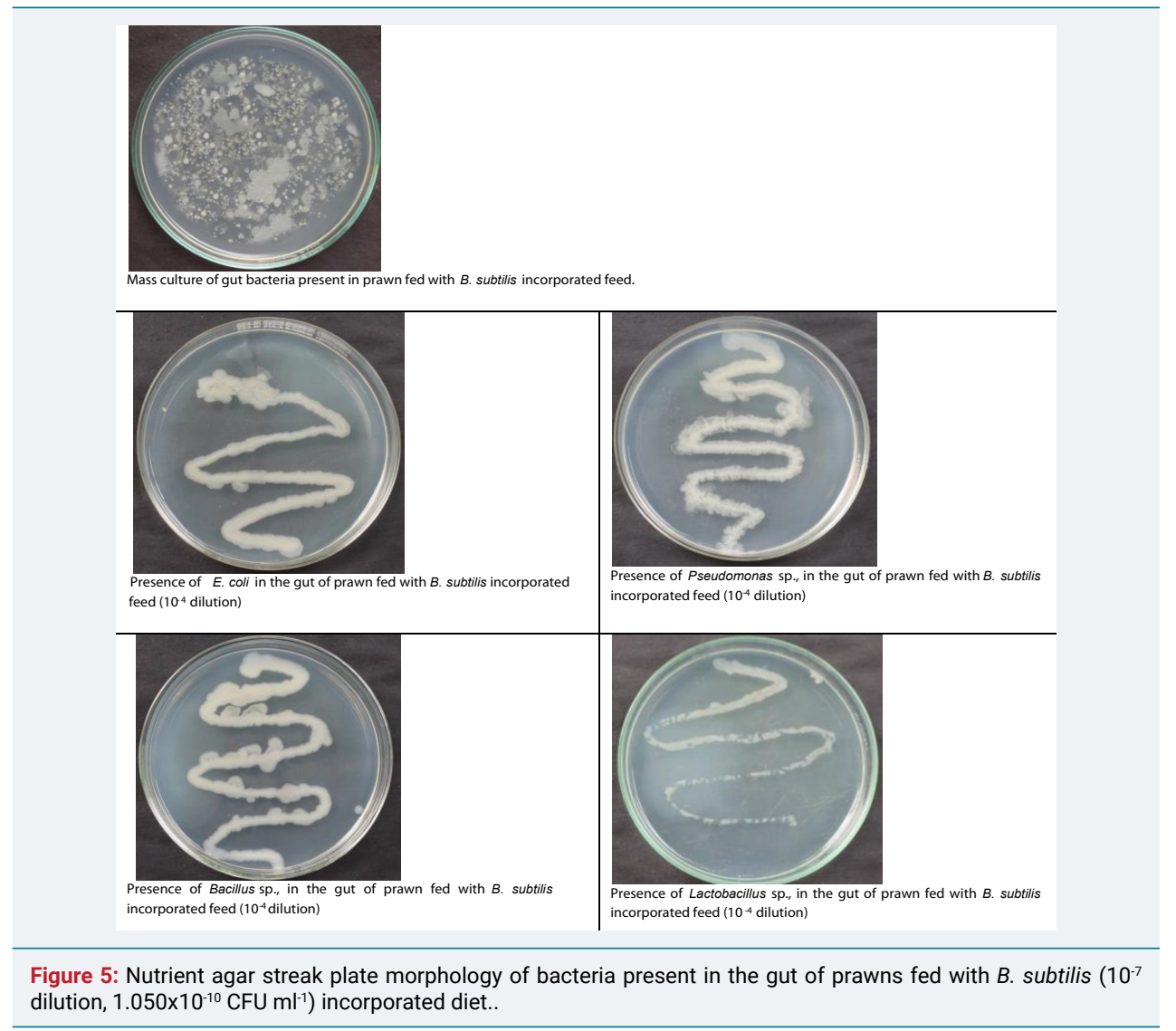

These results indicated that the supplemented probiotics have the characteristics ability to enhance the digestion, absorption of nutrients and alteration in the intestinal microflora, which led to better growth and survival of $M$. rosenbergii. It has been reported that the SR, WG, SGR, FCR and PER, carcase proximate composition, and activities of protease, amylase and lipase were significantly improved in $M$. rosenbergii fed with different probiotics, L. sporogenes, L. rhamnosus, L. ceremoris, L. acidophilus, B. subtilis, C. butyricum, B. coagulans, S. cerevisiae and commercial probiotic products, LactoBacil $^{\circledR}{ }_{\text {plus' }}$ ViBact*, Binifit ${ }^{\mathrm{TM}}$ and Biogen ${ }^{\circledR}$ incorporated diets [4-13,32-42]. Similarly, the dietary administration of Lactobacillus plantarum, Bacillus sp., and C. butyricum also produced a significant improvement in growth, carcase biochemical constituents, and activities of digestive enzymes in shrimps, Litopenaeus vannamei and Marsupenaeus japonicas [12,43-46].

It has been reported that Lactobacillus sp., supplemented feed significantly decrease the pathogenic bacteria (Enterobacteriacea, Aeromonas sp., and Pseudomonas sp.) in M. rosenbergii [47]. The probiotics play an important role in healthy maintenance gut microflora of the host, which prevents colonization of harmful bacteria and stimulates the immune system [48-51]. The presence of at least 10 bacterial genera Escherichia coli, Proteus sp., Lactococcus sp., Enterobacteria sp., Lactobacillus sp., Pseudomonas sp., Staphylococcus sp., Bacillus sp., Klebsiella sp., and Streptococcus sp., have been isolated from the gut of fishes Oreochromis niloticus and Clarias gariepinus [52].

\section{Conclusion}

Overall, these probiotics incorporated diets produced better growth and survival due to better FCR and activities of digestive enzymes, which in turn led to better nutritional profile. B. coagulans, and B. subtilis incorporated diets possessed the ability of competitively exclude Acetonobacter sp., Salmonella sp., and Pseudomonas sp., and Acetonobacter sp., and Salmonella sp., respectively. Therefore they are recommended as feed additives for sustainable culture of M. rosenbergii. 


\section{Acknowledgement}

The DST-SERB, and DST-FIST, Government of India, New Delhi, are gratefully acknowledged for the research facility provided. We sincerely acknowledge 2016-17 batch M.Sc., Zoology project students, P. Sangavi, and M. Vishnupriya, for conducting the feeding trials.

\section{References}

1. FAO. Fish stat plus-universal software for fishery statistical time series comments/inquiries sitemap Logine-Bulletin@ FAO. National aquaculture sector overview India. 2010.

2. FAO. Yearbook, Fishery statistics, aquaculture production. 2005.

3. El-Haroun ER, Goda AMAS, Chowdhury MAK. Effect of dietary probiotic Biogen (R) supplementation as a growth promoter on growth performance and feed utilization of Nile tilapia Oreochromis niloticus (L.). Aquaculture. 2006; 37: 1473-1480. Ref.: https://goo.gl/RJgLXx

4. Saad AS, Habashy MM, Khadiga SM. Growth response of the freshwater prawn, Macrobrachium rosenbergii (De Man), to diets having different levels of Biogen. World Applied Sciences Journal. 2009; 6: 550-556. Ref.: https://goo.gl/EoqR1H

5. Seenivasan C, Bhavan PS, Radhakrishnan S. Effect of probiotics (Binifit ${ }^{\mathrm{TM}}$ ) on survival, growth, biochemical constituents and energy budget of the freshwater prawn Macrobrachium rosenbergii post larvae. Aquaculture Elixir International Journal. 2011; 41: 5919-5927. Ref.: https://goo.gl/hMZDea

6. Seenivasan C, Radhakrishnan S, Muralisankar T, Saravanabhavan P. Influence of combined probiotics Lactobacillus sporogenes and Bacillus subtilis on survival, growth, biochemical changes and energy utilization performance of Macrobrachium rosenbergii (De Man 1879) post larvae. Journal of Ecobiotechnology. 2012; 4: 29-34. Ref.: https://goo.gl/DMxmZ5

7. Seenivasan C, Saravana Bhavan P, Radhakrishnan S, Muralisankar T. Effects of Probiotics on Survival Growth and Biochemical Constituents of Freshwater Prawn Macrobrachium rosenbergii Post Larvae. Turkish Journal of Fisheries and Aquatic Sciences. 2012; 12: 331-338. Ref.: https://goo.gl/BryXYs

8. Seenivasan C, Radhakrishnan S, Muralisankar T, Saravana Bhavan P. Efficacy of Probiotics on Survival, Growth, Biochemical Changes and Energy Utilization Performance of Macrobrachium rosenbergii (De Man 1879) Post-larvae. Journal of Scientific Research. 2012; 4: 729-740. Ref.: https://goo.gl/8gFu5L

9. Seenivasan C, Radhakrishnan S, MuralisankarT, Bhavan PS, et al. Effects of probiotics on survival growth and digestive enzymes activities in freshwater prawn Macrobrachium rosenbergii (De Man 1879). Proceedings of the Zoological Society, 2016; 69(1): 52-60. DOI:10.1007/s 12595-014-0123-6. Ref.: https://goo.gl/5a3Umq

10. Jayanthi L, Bhavan PS, Srinivasan V, Muralisankar T, Manickam N, et al. Probiotics product (LactoBacil®plus) on improvement of survival, growth, digestive enzymes activity, nutritional status and gut microflora of the prawn Macrobrachium rosenbergii. International Journal of Current Research. 2015; 7: $11440-11453$

11. Jayanthi L, Bhavan PS, Srinivasan V, Muralisankar T, Manickam N, et al. Dietary supplementation of probiotics product (ViBact*) on the survival, growth, biochemical constituents and gut microflora of the giant freshwater prawn Macrobrachium rosenbergii post-larvae. Asian Journal of Biochemical and Pharmaceutical Research. 2015; 2: 67-88.

12. Sumon MS, Ahmmed F, Khushi SS, Ahmmed MK, Rouf MA, et al. Growth performance, digestive enzyme activity and immune response of Macrobrachium rosenbergii fed with probiotic Clostridium butyricum incorporated diets. Journal of King Saud University-Science. 2016. Ref.: https://goo.gl/VaUDQw

13. Gupta A, Verma G, Gupta P. Growth performance, feed utilization, digestive enzyme activity, innate immunity and protection against Vibrio harveyi of freshwater prawn, Macrobrachium rosenbergii fed diets supplemented with Bacillus coagulans. Aquaculture International. 2016; 24: 1379-1392. Ref.: https:// goo.gl/YQSNmF

14. Karthik M, Saravana Bhavan P. Supplementation of Lactobacillus brevis for Growth Promotion of the Freshwater Prawn Macrobrachium rosenbergii Post Larvae and Identification of Gut Microflora through 16s rDNA. Research journal of biotechnology. 2018; 13: 34-50.

15. Hyronimus $B$, Le Marrec $C$, Urdacil M. Coagulin, a bacteriocin-like inhibitory substance produced by Bacillus coagulans, 14. Journal of Applied Microbiology. 1998; 85: 42-50. Ref.: https://goo.gl/dgNQJi

16. Hyronimus B, Le Marrec C, Sassi AH, Deschamps A. Acid and bile tolerance of spore-forming lactic acid 
bacteria. International Journal Food and Microbiololgy. 2000; 61: 193-197. Ref.: https://goo.gl/TBk7xw

17. Donskey CJ, Hoyen CK, Das SM, Farmer S, Dery M, et al. Effect of oral Bacillus coagulans administration on the density of vancomycin-resistant Enterococci in the stool of colonized mice. Letters in Applied Microbiology. 2001; 33: 84-88. Ref.: https://goo.gl/4X3GsH

18. Pinchuk IV, Bressollier P, Verneuil B, Fenet B, Sorokulova IB, et al. In vitro anti-Helicobacter pylori activity of the probiotic strain Bacillus subtilis 3 is due to secretion of antibiotics. Antimicrobial Agents and Chemotherapy. 2001; 45: 3156-3161. Ref.: https://goo.gl/WtU5e2

19. APHA. 2005. Standard Methods for the Examination of Water and Wastewater. 21st Edn, American Public Health Association, Washington, DC., USA. 2005

20. Winkler LW. Die Best immung des in Wasser gelosten Sauerstoffen. Ber Dtsch Chem Ges. 1888.21: 28432855.

21. Solorzano L. Determination of ammonia in natural waters by the Phenolhypochlorite method. Limnology and Oceanography. 1969; 14: 799-801. Ref.: https://goo.gl/2EX5qJ

22. AOAC. Official methods of analysis of AOAC international. Vols. 2, 16th edn. Arlington, VA, USA, Association of Analytical Communities. 1995. Ref.: https://goo.gl/a73bz3

23. Tekinay AA, Davies SJ. Dietary carbohydrate level influencing feed intake, nutrient utilization and plasma glucose concentration in the rainbow trout, Oncorhynchus mykiss. Turkish journal of veterinary and animal sciences. 2011; 25: 657-666. Ref.: https://goo.gl/Mfc8DS

24. Lowry OH, Rosenbrough WJ, Fair AL, Randall RJ, Rose J Randall. Protein measurement with the Folinphenol reagent. The Journal of Biological Chemistry. 1951; 193: 265-275. Ref.: https://goo.gl/jJ2BMR

25. Moore S, Stein WH. Polyphenol oxidase. In: Methods in Enzymol. (eds. by S.P. Colowick \& N.D. Kaplan), Academic Press, New York, 1948.

26. Roe $\mathrm{JH}$. The determination of sugar and blood and spinal fluid with anthrone reagent. The Journal of Biological Chemistry. 1955; 212: 335-343. Ref.: https://goo.gl/1swAQm

27. Folch J, Lees M, Bloane Stanley GH. A simple method for the isolation and purification of total lipids from animal tissues. Journal of Biological Chemistry. 1957; 266: 497-509.

28. Barnes $\mathrm{H}$, Blackstock J. Estimation of lipids in marine animals and tissues. Detail investigation of the sulpho-phosphovanillin method for total lipids. Journal of Experimental Marine Biology and Ecology. 1973; 12: 103-118. Ref.: https://goo.gl/uXaxra

29. Furne M, Hidalgo MC, Lopez A, Garcia-Gallego M, Morales AE, et al. Digestive enzyme activities in Adriatic sturgeon Acipenser naccarii and rainbow trout Oncorhynchus mykiss, A comparative study. Aquaculture. 2005; 250: 391-398. Ref.: https://goo.gl/vJ6yc1

30. Bernfeld P. Amylases alpha and beta. Methods in enzymology. Academic Press. 1955; 140-146.

31. Holt JG, Krie NR, Sneath PHA, Stately JT, Williams ST. Bergey's Manual of Determinative Bacteriology, 9th Ed, Baltimore, Williams and Wilkins. 1996; 787.

32. Suralikar V, Sahu NP. Effect of feeding probiotic (Lactobacillus cremoris) on growth survival of Macrobrachium rosenbergii postlarvae. Journal of Applied Animal Research. 2001; 20: 117-124. Ref.: https://goo.gl/TzcirL

33. Keysami MA, Saad CR, Sijam K, Daud HM, Alimon AR. Effect of Bacillus subtilis on growth development and survival of postlarvae Macrobrachium rosenbergii (de Man). Aquaculture Nutrition. 2007; 13: 131136. Ref.: https://goo.gl/v4kot5

34. Shinde AN, Mulye VB, Chogale ND, Bhatkar VR, Bondre RD, et al. Effect of different probiotics on Macrobrachium rosenbergii (De Man) post larvae. Aquaculture. 2008; 9: 7-12.

35. Rinisha K, Mujeeb Rahiman KM, RaziaBeevi M, Thomas AP, Mohamed Hatha AA, et al. Probiotic Effects of Bacillus spp. On the growth and survival of postlarvae of Macrobrachium rosenbergii. Fishery Technology. 2010; 47: 173-178.

36. Mujeeb Rahiman KM, Jesmi Y, Thomas AP, Mohamed Hatha AA. Probiotic effect of Bacillus NL110 and Vibrio NE17 on the survival, growth performance and immune response of Macrobrachium rosenbergii (De Man). Aquaculture Research. 2010; 41: 120-134. Ref.: https://goo.gl/6fRpPg

37. Lahteinena $T$, Lindholma A, Rinttilaa $T$, Junnikkalaa $S$, Kant $R$, et al. Effect of Lactobacillus brevis ATCC 8287 as a feeding supplement on the performance and immune function of piglets. Veterinary Immunology and Immunopathology. 2013; 158: 14-25. Ref.: https://goo.gl/ZUM2JY

38. Zarif BR, Azin M. Identifying probiotics of Macrobrachium rosenbergii's intestine micro flora and 
their effect in prawn's growth and survival. Advances in Life Sciences. 2014; 4: 123-130. Ref.: https://goo.gl/9XckTM

39. Prasuna Devi DV, Hareesh K, Srinivasulu Reddy M. Studies on the proximate composition of tropical freshwater prawn Macrobrachium rosenbergii. International Journal of Fisheries and Aquatic Studies. 2015; 3: 329-336. Ref.: https://goo.gl/Ssc7w6

40. Venkat HK, Sahu NP, Jain KK. Effect of feeding Lactobacillus based probiotics on the gut microflora, growth and survival of post larvae of Macrobrachium rosenbergii (de Man). Aquaculture Research. 2004; 35: 501-507. Ref.: https://goo.gl/mhCNbP

41. Deeseenthum S, Leelavatcharams V, Brook DJ. Effects of feeding Bacillus sp. as probiotic bacteria on growth of giant freshwater prawn Macrobrachium rosenbergii (De man). Pakistan Journal of Biological Sciences. 2007; 10: 1481-1485. Ref.: https://goo.gl/z42hVc

42. Seenivasan C, Radhakrishnan S, Shanthi R, Muralisankar T, Bhavan PS. Influence of probiotics on survival, growth, biochemical changes and energy utilization performance of Macrobrachium rosenbergii post-larvae. Proceedings of the Zoological Society, 2015; 68: 74-83. Ref.: https://goo.gl/BYkZXK

43. Ziaei Nejad S, Rezaei MH, Takami GA, Lovett DL, Mirvaghefi AR, et al. The effect of Bacillus spp. bacteria used as probiotics on digestive enzyme activity, survival and growth in the Indian white shrimp, Fenneropenaeus indicus. Aquaculture. 2006; 252: 516-524. Ref.: https://goo.gl/kLPLJZ

44. Wang YB, Xu ZR. Effect of probiotics for common carp (Cyprinus carpio) based on growth performance and digestive enzyme activities. Animal Feed Science and Technology. 2006; 127: 283-229. Ref.: https://goo.gl/eMdnBW

45. Yu MC, Li ZJ, Lin HZ, Wen GL, Ma Shen. Effects of dietary medicinal herbs and Bacillus on survival, growth, body composition, and digestive enzyme activity of the white shrimp Litopenaeus vannamei. Aquaculture International. 2009; 17: 377-384. Ref.: https://goo.gl/FSggXJ

46. Zheng $X$, Duan $Y$, Dong $H$, Zhang J. Effects of dietary Lactobacillus plantarum in different treatments on growth performance and immune gene expression of white shrimp Litopenaeus vannamei under normal condition and stress of acute low. Salinity. Fish and Shellfish Immunology. 2017; 62: 195-201. Ref.: https://goo.gl/eNYU3N

47. Dash G, Raman RP, Prasad KP, Marappan M, Pradeep MA, et al. Evaluation of Lactobacillus plantarum as a water additive on host associated microflora, growth, feed efficiency and immune response of giant freshwater prawn, Macrobrachium rosenbergii (de Man, 1879). Aquaculture Research. 2014; 47: 804-818. Ref.: https://goo.gl/kdeHTW

48. Cain K, Swan C. Barrier function and immunology. In: The Multifunctional Gut of Fish (ed. by M. Grosell, A.P. Farrell \& C.J. Brauner). 2010; 111-134.

49. Gaggia F, Mattarelli $P$, Biavati B. Probiotics and prebiotics in animal feeding for safe food production. International Journal of Food Microbiology. 2010; 14: 15-28. Ref.: https://goo.gl/Xh8TyW

50. Gomez GD, Balcazar JL. A review on the interactions between gut microbiota and innate immunity of fish. FEMS Immunology and Medical Microbiology. 2008; 52: 145-154. Ref.: https://goo.gl/YvrPfL

51. Rungrassamee W, Klanchui A, Chaiyapechara S, Maibunkaew S, Tangphatsornruang S, et al. Bacterial population in intestines of the black tiger shrimp (Penaeus monodon) under different growth stages. Plos one. 2013. Ref.: https://goo.gl/X6gGNV

52. Charles DK, Mark BM, Samuel M, Andrew T, Nathan LM, et al. Isolation and Identification of Potential Probiotics Bacteria from the Gut of Oreochromis niloticus and Clarias gariepinus in Uganda. British Microbiology Research Journal. 2016. Ref.: https://goo.gl/N7w38j 